\title{
PENGARUH MODEL PEMBELAJARAN VALUE CLARIFICATION TECHNIQUE BERBASIS TRI KAYA PARISUDHA TERHADAP SIKAP SOSIAL SISWA PADA MATA PELAJARAN PKN KELAS V
}

\author{
Ni Wayan Tutik Santika Dewi ${ }^{1}$, I Made Citra Wibawa1 ${ }^{1}$, I Gusti Ayu Tri Agustiana² \\ 1 Jurusan Pendidikan Dasar, Universitas Pendidikan Ganesha, Singaraja, Indonesia \\ 2 Jurusan Pendidikan Dasar, Universitas Pendidikan Ganesha, Singaraja, Indonesia \\ ${ }^{3}$ Jurusan Pendidikan Dasar, Universitas Pendidikan Ganesha, Singaraja, Indonesia \\ e-mail: \{tutikdewi59@yahoo.com1, ,imadecitra.wibawa@undiksha.ac.id2, igustiayutriagustiana@yahoo.co.id3 \}
}

\begin{abstract}
ABSTRAK
Penelitian ini bertujuan untuk mengetahui pengaruh model pembelajaran value clarification technique berbasis tri kaya parisudha terhadap sikap sosial siswa pada mata pelajaran PKn siswa kelas V SD Gugus VI Kecamatan Tegalalang. Jenis penelitian ini adalah eksperimen semu dengan rancangan non-equivalent post test only group design. Populasi dari penelitian ini adalah seluruh siswa kelas V SD Gugus VI Kecamatan Tegalalang tahun pelajaran 2018/2019 yang berjumlah 111 siswa. Sampel penelitian ini yaitu Kelas V SDN 2 Tegalalang yang berjumlah 28 siswa dan SDN 3 Keliki yang berjumlah 31 orang. Data sikap sosial mata pelajaran PKn dikumpulkan dengan instrumen berupa kuesioner. Data yang dikumpulkan dianalisis dengan menggunakan teknik analisis statistik deskriptif dan statistic inferensial yaitu (uji-t). Berdasarkan hasil analisis data, diperoleh $=13,376$ dan t tabel $=2,002$ (pada taraf signifikansi 5\%). Hal ini berarti bahwa $t$ hitung $>t$ tabel sehingga dapat diinterpretasikan bahwa terdapat pengaruh yang signifikan Model Pembelajaran Value Clarification Technique Berbasis Tri Kaya Parisudha terhadap Sikap Sosial pada mata pelajaran PKn siswa kelas V Gugus VI Kecamatan Tegalalang.
\end{abstract}

Keywords: value clarification technique, tri kaya parisudha, sikap sosial, $\mathrm{PKn}$

\section{PENDAHULUAN}

Pendidikan sekolah dasar (SD) sebagai jenjang paling dasar pada pendidikan formal mempunyai peran besar bagi keberlangsungan proses. Pendidikan SD sebagai titik awal pendidikan formal yang memiliki andil besar sebagai pondasi pengetahuan untuk berkelanjutan pendidikan. Pendidikan di sekolah dasar diharapkan memberikan pengetahuan yang bermakna sehingga mampu menjadikan pondasi yang kokoh bagi siswanya. Oleh karena itu, guru harus mampu memberikan pengetahuan dan keterampilan tentang nilai-nilai 
kehidupan bagi siswanya sehingga siswa memiliki pemahaman akan nilai luhur bangsa dan moral untuk meningkatkan kualitas siswa dalam bermasyarakat berbangsa dan bernegara.

Salah satu mutu mata pelajaran yang perlu ditingkatkan adalah mata pelajaran Pendidikan Kewarganegaraan (PKn) karena tolak ukur kemajuan suatu bangsa dilihat dari sikap dan perilaku seseorang. PKn merupakan salah satu mata pelajaran yang dianggap turut ikut serta dalam membentuk kepribadian siswa. Susanto (2013:225) menyatakan bahwa "Pendidikan Kewarganegaraan adalah mata pelajaran yang digunakan sebagai wahana untuk mengembangkan dan melestarikan nilai luhur dan moral yang berakar pada budaya Indonesia". Tujuan dari PKn adalah untuk meningkatkan perilaku baik yang dimiliki oleh siswa agar nantinya siswa mampu mengamalkan nilai-nilai Pancasila dengan baik dalam kehidupannya sehari-hari. Dianti (2016) menyatakan bahwa :

Permasalahan yang didapatkan di lapangan adalah praktek pendidikan dalam pembelajaran PKn yang berlangsung di kelas pada saat ini hanyalah sebatas pendidikan yang berorinetasi pada pencapaian tujuan kognitif atau pengetahuan saja. Sedangkan afektif, hal yang berkaitan dengan proses pembentukan karakter/sikap siswa cenderung diabaikan.

Hal ini Nampak dari kurang seimbangnya perkembangan intelektual dengan kecerdasan emosional siswa. Pendidikan saat ini yang lebih mementingkan aspek kognitif terlihat dari adanya pelaksanaan Ujian Nasional sebagai penentu kelulusan siswa dari jenjang SD hingga SMA. Keberhasilan pembelajaran yang diukur melalui pelaksanaan UN dari tahun ke tahun terus mengalami permasalahan yang semakin memperburuk citra pendidikan di Indonesia. Salah satu permasalahan yang terjadi adalah persiapan pemerintahan yang kurang matang dalam pelaksanaan UN itu sendiri. Kurang matangnya pelaksanaan UN seperti banyaknya paket soal yang membingungkan para siswa dan kecurangan yang dilakukan oleh pihak sekolah (Ismail 2015). Dengan demikian, pelaksanaan UN tidak memberikan kesempatan untuk siswa mengembangkan sikap yang jujur, melainkan menumbuhkan kebiasaan siswa untuk menghalalkan segala cara untuk dapat menjawab soal-soal UN. Hal ini pada akhirnya akan menimbulkan krisis nilai pada diri siswa.

Salah satu bentuk krisis nilai yang dialami oleh siswa salah satunya berupa tawuran pelajar di kota-kota besar di Indonesia. Kasus tawuran antar pelajar menjadi salah satu permasalahan serius dalam dunia pendidikan. Selain itu, krisis nilai yang paling sering terjadi terlihat dari kebiasaan siswa saling ejek dan bermusuhan dengan temannya sendiri, berkata kasar, dan tidak menghormati guru. Kebiasaan-kebiasaan tersebut timbul karena perkembangan intelektual siswa tidak diimbangi dengan pembentukan dan penanaman nilai moral yang baik dan kurangnya penanaman nilai sejak dini. Hal ini didukung oleh hasil observasi dan wawancara yang dilakukan di SD Gugus VI Kecamatan Tegalalang Kabupaten Gianyar, yang terdiri 4 SD, yaitu SDN 1 Keliki, SDN 2 Keliki, SDN 3 Keliki dan SDN 2 Tegalalang.

Berdasarkan hasil wawancara yang dilakukan tanggal 14 Januari 2019 dengan guru PKn pada keempat sekolah tersebut diperoleh beberapa informasi terkait dengan pelaksanaan 
pendidikan nilai di masing-masing sekolah. Secara umum, pendidikan nilai sudah diterapkan pada pembelajaran PKn melalui penyampaian pesan moral dan penanaman karakter secara lisan. Para guru tersebut juga menyebutkan bahwa penyampaian pesan tersebut sudah diupayakan untuk dapat merubah karakter dan sikap siswa. Namun kenyataannya guru-guru tersebut juga mengakui bahwa penyampaian pesan dan nasehat yang telah mereka lakukan secara lisan masih belum menampakkan hasil yang optimal. Hal tersebut dikarenakan sikap siswa yang kembali seperti semula setelah pemberian nasehat tersebut dilakukan.

Hasil wawancara tersebut juga didukung oleh hasil observasi tanggal 15 Januari 2019 saat proses pembelajaran berlangsung di kelas yaitu cara guru mengelola pembelajaran masih terpusat pada pengembangan aspek kognitif saja dengan cara penyampaian berupa ceramah. Dalam pemberian materi yang didominasi oleh ceramah dan pemberian tugas, guru lebih banyak menekankan pada pemahaman materi siswa dan sedikit menyentuh ranah afektif siswa. Pada akhir pembelajaran, guru hanya sedikit memberikan penekanan nilai moral pada siswa yang dilakukan secara lisan. Penyampaian pesan moral secara lisan yang dilakukan secara sepihak oleh guru tanpa melibatkan siswa dalam memahami nilai-nilai yang diterimanya, terlihat kurang efektif. Ini dikarenakan siswa hanya paham tentang nasehat yang diberikan oleh guru pada saat di kelas, namun sikap siswa akan kembali seperti semula saat berada di luar kelas. Dengan pelaksanaan dan penanaman nilai yang belum optimal di SD Gugus VI Kecamatan Tegalalang, maka tidak heran jika masih banyak terlihat sikap dan perilaku siswa yang kurang baik seperti sering ribut di kelas, mengganggu teman, tidak menghormati guru dan tidak konsentrasi saat diberikan pengarahan oleh guru.

Berdasarkan data yang diperoleh dari wali kelas V di SD Gugus VI kecamatan Tegalalang diketahui bahwa nilai rata-rata PKn siswa kelas V SD Gugus VI Kecamatan Tegalalang berada pada kategori cukup. Hal ini menandakan bahwa nilai rata-rata UAS PKn Siswa Kelas V SD Gugus VI Kecamatan Tegalalang dapat di klarifikasikan sikap sosial rendah.

Rendahnya sikap sosial tersebut dipengaruhi oleh beberapa faktor. Salah satu faktor yang sangat mempengaruhi sikap sosial siswa adalah kurangnya inovasi dalam pelaksanaan pembelajaran sehingga pesan moral dan nilai yang diharapkan sampai pada siswa tidak tersampaikan dan pada akhirnya tidak membuat perubahan sikap siswa ke arah yang lebih baik. Maka perlu adanya inovasi-inovasi baru dalam pelaksanaan pembelajaran PKn yang mampu meningkatkan kesadaran nilai yang nantinya dapat membentuk sikap siswa ke arah yang lebih baik. Salah satu bentuk inovasi yang ditawarkan adalah dengan menggunakan model pembelajaran yang sesuai dengan tujuan pendidikan nilai dan pembentukan sikap siswa. Model pembelajaran yang sesuai dengan tujuan pendidikan nilai dan pembentukan sikap siswa adalah model pembelajaran Value Clarification Technique (VCT) yang berbasis tri kaya parisudha.

Nunuk (2012:131) menyatakan bahwa,

model VCT merupakan teknik pengajaran untuk membantu siswa dalam menerima dan menentukan suatu nilai yang di anggapnya baik dalam menghadapi suatu persoalan melalui proses menganalisis nilai yang sudah ada dan tertanam dalam diri siswa. VCT menekankan bagaimana sebenarnya seseorang membangun nilai yang menurut anggapannya baik, yang 
pada akhirnya nilai-nilai tersebut akan mewarnai perilaku dalam kehidupan sehari-hari di masyarakat.

Berdasarkan pemaparan di atas, maka penggunaan model pembelajaran $V C T$ dalam pelajaran PKn diharapkan akan terjadinya perubahan sikap dan tingkah laku yang berdasarkan tuntunan moral-nilai pancasila, sebab pancasila bukan semata-mata untuk dimengerti, melainkan untuk dihayati dan diamalkan. Pendidikan nilai yang dibelajarkan dengan model VCT pada dasarnya sejalan dengan ajaran setiap agama yang menekankan pada nilai-nilai kebaikan yang pada akhirnya diharapkan mampu melahirkan manusia dengan etika yang baik. Salah satu konsep dalam ajaran etika agama Hindu yang sesuai dengan tujuan pelaksanaan pendidikan nilai dan model VCT adalah konsep Tri Kaya Parisudha. Tri Kaya Parisudha adalah tiga dasar perilaku manusia yang harus disucikan yang mencakup manacika (pikiran), wacika (perkataan) dan kayika (perbuatan). Rustiana, (2018:194) menyatakan bahwa "Tri kaya parisudha as three basic human behaviors that must be sanctified include good at thinking, good at words and good at behave". Adanya konsep tri kaya parisudha siswa akan cenderung untuk melakukan sesuatu untuk mencapai tujuan yang ingin dicapai. Karena sikap dan prilaku baik yang dimiliki siswa sangat berperan untuk meningkatan hasil belajar siswa.

Berdasarkan uraian latar belakang tersebut, maka dilakukan penelitian yang berjudul "Pengaruh Model Pembelajaran Value Clarification Technique (VCT) berbasis tri kaya parisudha terhadap Sikap Sosial Siswa Pada Mata Pelajaran PKn Kelas V SD Gugus VI Kecamatan Tegalalang Tahun Pelajaran 2018/2019".

\section{METODE}

Penelitian ini dilaksanakan pada siswa kelas V SD Gugus VI Kecamatan Tegalalang Tahun Pelajaran 2018/2019 dari bulan Januari sampai bulan Mei 2019. Jenis penelitian ini adalah penelitian eksperimen semu (quasi eksperimen) karena tidak semua vaiabel dapat dikontrol secara ketat. Rancangan yang digunakan dalam penelitian ini adalah nonequivalent post test only control group design.

Dalam penelitian ini populasi yang digunakan adalah keseluruhan siswa kelas V sekolah dasar di Gugus VI Kecamatan Tegalalang, Tahun Pelajaran 2018/2019.

Sebelum pengambilan sampel langkah pertama yang harus dilakukan adalah menguji kesetaraan. Uji kesetaraan dilakukan untuk mengetahui setara atau tidaknya kemampuan akademik kelompok sampel. Uji kesetaraan dilakukan dengan uji Anava A (Anava Satu Jalur) dengan bantuan Microsoft excel 2007 diperoleh $\mathrm{F}$ hitung sebesar 1,01. Hasil perhitungan tersebut menunjukan bahwa F hitung lebih kecil dari F tabel $(1,01<2,70)$ untuk taraf signifikan $5 \%$. Berdasarkan uji kesetaraan yang dilakukan ke empat SD yang ada di Gugus VI Kecamatan Tegalalang memiliki kemampuan yang setara. Dalam pemilihan sampel dilakukan dengan cara pengundian secara acak dan untuk menentukan kelas eksperimen dan kelas control dilakukan pengundian kembali. Hasil pengundian tersebut adalah SDN 2 Tegalalang sebagai kelas eksperimen yang berjumlah 28 orang dan SDN 3 Keliki sebagai kelas control yang berjumlah 31 orang.

Penelitian ini terdapat dua variabel yaitu variabel bebas dan variabel terikat. Variabel bebas pada penelitian ini adalah model pembelajaran Value Clarification Technique (VCT) berbasis tri 
kaya parisudha sedangkan variabel terikat pada penelitian ini adalah sikap sosial siswa pada mata pelajaran PKn.

Metode yang digunakan dalam penelitian ini adalah metode nontes berupa angket. Angket yang digunakan adalah angket pertanyaan tertutup yaitu siswa hanya memilih jawaban yang tersedia pada angket tersebut. Kuesioner adalah cara memperoleh atau mengumpulkan data dengan cara mengirimkan atau memberikan daftar pernyataan-pernyataan kepada responden atau subjek penelitian. Kuesioner yang dilakukan dalam penelitian ini adalah kuesioner sikap sosial yang berjumlah 35 butir. Instrument nontes sikap sosial siswa akan diuji cobakan terlebih dahulu sebelum diberikan kepada kelas eksperimen dan kelas control. Hal tersebut dilakukan untuk mengetahui valid atau tidak, dan reliabilitas.

Data yang terkumpul kemudian dianalisis menggunakan teknik analisis statistik deskriptif dan inferensial. Teknik analisis deskriptif digunakan untuk mencari mean, median, modus, varians dan standar deviasi. Sedangkan teknik analisis inferensial digunakan untuk mencari uji normalitas, uji homogenitas dan uji hipotesis.

Uji hipotesis yang dilakukan pada penelitian ini adalah analisis uji-t. hal tersebut dikarenakan membandingkan satu variabel bebas dan satu variabel terikat. Uji hipotesis yang digunakan yaitu sampel independent (sampel tidak berkolerasi) dengan rumus polled varians. Kriteria penguji adalah $\mathrm{H}$ diterima jika dan $\mathrm{H}$ ditolak jika pada taraf signifikansi 5\%.

\section{HASIL DAN PEMBAHASAN}

Data penelitian ini adalah skor sikap sosial siswa sebagai akibat dari pengaruh model pembelajaran VCT berbasis tri kaya parisudha pada kelompok eksperimen dengan siswa yang dibelajarkan dengan model pembelajaran konvensional pada kelompok kontrol. Rangkuman hasil analisis data deskriptif disajikan pada table berikut.

Tabel Deskripsi Data Sikap Sosial Kelompok Eksperimen dan Kelompok Kontrol

\begin{tabular}{lll}
\hline Hasil Analisis & Kelompok Eksperimen & Kelompok Kontrol \\
\hline Mean & 124,25 & 109,26 \\
Median & 124,86 & 108,82 \\
Modus & 125,25 & 108,25 \\
Varians & 18,78 & 18,21 \\
Standar Deviasi & 4,33 & 4,27 \\
\hline
\end{tabular}


Data sikap sosial pada mata pelajaran PKn yang diperoleh melalui pemberian post-test terhadap 28 orang yang dibelajarkan dengan model pembelajaran VCT berbasis tri kaya parisudha menunjukkan bahwa skor tertinggi adalah 132 dan skor terendah adalah 115 Berdasarkan perhitungan mean, median, modus dan dengan mengamati tabel di atas, diketahui Mo > Me > M pada kelompok eksperimen, jika disajikan pada grafik polygon maka gambar tersebut menunjukkan grafik juling negatif, yang artinya bahwa rata-rata skor sikap sosial siswa yang dibelajarkan menggunakan model pembelajaran VCT berbasis tri kaya parisudha cenderung tinggi. Berdasarkan pedoman konversi skala lima, maka rata-rata skor $(M)=124,25$ hasil konversi mean kelompok eksperimen berada pada kategori sangat baik. Data sikap sosial pada mata pelajaran PKn kelompok eksperimen dapat disajikan ke dalam bentuk grafik polygon seperti gambar berikut.

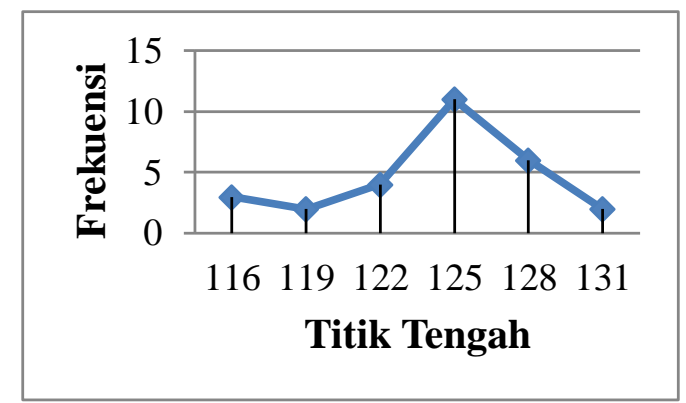

Data sikap sosial pada mata pelajaran PKn yang diperoleh melalui pemberian post-test terhadap 31 orang pada kelompok kontrol menunjukkan bahwa skor tertinggi adalah 118 dan skor terendah adalah 101. Berdasarkan perhitungan mean, median, modus, diketahui Mo $<\mathrm{Me}<\mathrm{M}$, jika disajikan pada grafik polygon seperti gambar berikut.

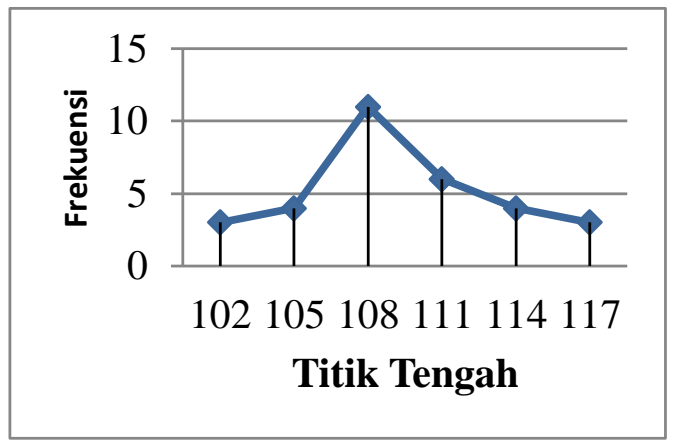

maka gambar tersebut menunjukkan grafik juling positif, yang artinya bahwa rata-rata skor sikap sosial siswa pada kelompok kontrol cenderung rendah. Berdasarkan pedoman konversi skala lima, maka rata-rata skor $(M)=109,26$ hasil konversi mean kelompok kontrol berada pada kategori cukup. Data sikap sosial kelompok kontrol dapat disajikan ke dalam bentuk grafik polygon seperti gambar berikut.

Untuk memenuhi uji prasyarat sebelum dianalisis menggunakan uji-t maka terlebih dahulu harus memenuhi beberapa asumsi statistic yaitu Uji Normalitas dan Uji Homogenitas. Uji normalitas dilakukan untuk menentukan dan membuktikan bahwa frekuensi data hasil penelitian benar- benar berdistribusi normal. Uji normalitas dilakukan terhadap data sikap sosial pada mata pelajaran PKn kelompok eksperimen dan kelompok kontrol. Normalitas sebaran data diuji dengan menggunakan rumus Chi-Kuadrat $\left(X^{2}\right)$ 
dengan kriteria pengujian data berdistribusi normal jika $X^{2}$ hitung $<X^{2}$ tabel pada taraf signifikansi $5 \%$ dengan $\mathrm{dk}=$ jumlah kelas - parameter -1 .

Berdasarkan hasil perhitungan dengan menggunakan rumus Chi-Kuadrat, diperoleh $X^{2}$ hitung pada kelompok eksperimen adalah 5,881 dan $X^{2}$ tabel dengan taraf signifikansi 5\% dan $\mathrm{db}=3$ adalah 7,815. Hal ini berarti $X^{2}$ hitung sikap sosial siswa pada mata pelajaran PKn kelompok eksperimen lebih kecil dari $X^{2}$ tabel $\left(X^{2}\right.$ hitung $<X^{2}$ tabel $)$ sehingga data hasil pada kelompok eksperimen berdistribusi normal.

Sedangkan $X^{2}$ hitung pada kelompok kontrol adalah 3,829 dan $X^{2}$ tabel dengan taraf signifikansi $5 \%$ dan $\mathrm{db}=3$ adalah 7,815. Hal ini berarti $X^{2}$ hitung sikap sosial siswa pada mata pelajaran PKn kelompok kontrol lebih kecil dari $X^{2}$ tabel $\left(X^{2}{ }_{\text {hitung }}<X^{2}\right.$ tabel $)$ sehingga data sikap sosial pada kelompok kontrol berdistribusi normal.

Uji homogenitas data dilakukan terhadap data sikap sosial siswa pada mata pelajaran PKn yang terdiri dari dua kelompok yaitu kelompok eksperimen dan kelompok kontrol. Uji homogenitas varians ini dilakukan untuk data homogen jika $F_{\text {hitung }}<F_{\text {tabel. }}$ Uji homogenitas ini dilakukan untuk mengetahui apakah kedua sampel homogen. Dari perhitungan yang dilakukan diperoleh $F_{\text {hitung }}$ sikap sosial siswa adalah 1,03 sedangkan $F_{\text {tabel }}$ dengan $d b$ pembilang $=27, \mathrm{db}_{\text {penyebut }}=30$ dan taraf signifikan $5 \%$ adalah 4,01 . Hal ini berarti $\mathrm{F}_{\text {hitung }}$ lebih kecil dari $F_{\text {tabel }}(1,03<4,01)$ sehingga varians data sikap sosial siswa pada mata pelajaran PKn kedua kelompok adalah homogen.

Pengujian hipotesis dilakukan dengan menggunakan uji-t sampel independent (tidak berkolerasi) dengan rumus polled varians dengan kriteria $\mathrm{H}_{0}$ ditolak jika $t_{\text {hitung }}>t_{\text {tabel }}$ dan $\mathrm{H}_{0}$ diterima jika $t_{\text {hitung }}<t_{\text {tabel. }}$ Pada uji hipotesis $t_{\text {tabel }}$ diperoleh dari tabel distribusi $t$ dengan taraf signifikan $5 \%$ dan derajat kebebasan $d b=n 1+n 2-2$. Berikut adalah rangkuman hasil perhitungan uji-t antar kelompok eksperimen dan kelompok kontrol disajikan pada tabel.

Tabel Hasil Perhitungan Uji-t

\begin{tabular}{lllllll}
\hline Kelompok & $\mathrm{N}$ & $\mathrm{Db}$ & $\bar{X}$ & $\mathrm{~S}$ & $\mathrm{t}_{\text {hitung }}$ & $\mathrm{t}_{\text {tabel }}$ \\
\hline Eksperimen & 28 & 57 & 124,25 & 18,78 & \multirow{2}{*}{13,376} & 2,002 \\
Kontrol & 31 & 57 & 109,26 & 18,21 & & \\
\hline
\end{tabular}

Hasil perhitungan uji-t, diperoleh $t_{\text {hitung }}$ sebesar 13,376 dan $t_{\text {tabel }}$ untuk $d b=57$ dengan taraf signifikan $5 \%$ adalah 2,002. Berdasarkan kriteria pengujian, karena $t_{\text {hitung }}>t_{\text {tabel }}$ maka $\mathrm{H}_{0}$ ditolak dan $\mathrm{H}_{1}$ diterima. Diterimanya $\mathrm{H}_{1}$ berarti terdapat pengaruh yang signifikan model pembelajaran VCT berbasis tri kaya parisudha terhadap sikap sosial siswa pada mata pelajaran PKn kelas V SD di Gugus VI Kecamatan Tegallalang Tahun Pelajaran 2018/2019.

\section{PEMBAHASAN}

Berdasarkan hasil analisis data penelitian menunjukan bahwa terdapat pengaruh yang signifikan sikap sosial siswa antara menggunakan model pembelajaran VCT berbasis tri kaya parisudha dengan menggunakan model konvensional. Hal ini dibuktikan dari nilai pada rata-rata skor sikap sosial siswa yang dibelajarkan dengan model VCT berbasis tri kaya parisudha adalah 124,25 yang berada di kategori sangat tinggi. Sedangkan rata-rata skor sikap sosial yang dibelajarkan dengan model pembelajaran konvensional adalah 109,26 
yang berada di kategori tinggi. Dengan demikian penggunaan model pembelajaran $V C T$ berbasis tri kaya parisudha berpengaruh terhadap sikap sosial siswa.

Skor yang diperoleh pada sikap sosial siswa kelompok eksperimen yang disajikan dalam gambar kurva polygon menunjukkan bahwa kurva sebaran data menunjukan kurva juling negatif hal ini berarti skor kelompok eksperimen sebagian besar skor sikap sosial siswa cenderung tinggi. Sedangkan skor yang diperoleh pada kelompok kontrol menunjukan kurva juling positif hal ini artinya skor sikap sosial siswa pada kelompok kontrol cenderung rendah.

Hasil perhitungan $t_{\text {hitung }}$ sikap sosial siswa diperoleh $t_{\text {hitung }}$ sebesar $13,376, t_{\text {hitung }}$ tersebut selanjutnya dibandingkan dengan $t_{\text {tabel }}$ pada taraf signifikansi $5 \%$ dengan $\mathrm{db}=\mathrm{n} 1$ $+\mathrm{n} 2-2=3=28+31-2=57$ adalah sebesar 2,002. Hal tersebut menunjukan bahwa $t_{\text {hitung }}$ $>t_{\text {tabel }}(13,376>2,002)$. Untuk membuktikan bahwa penggunaan model pembelajaran VCT berbasis tri kaya parisudha lebih baik dibandingkan model pembelajaran konvensional., maka peneliti melakukan pengamatan pada proses pembelajaran berlangsung. Berdasarkan pengamatan sikap sosial siswa yang dilakukan dalam proses pembelajaran membuktikan bahwa kelompok eksperimen skor pengamatan sikap sosial yang telah dilakukan menunjukan bahwa skor pengamatan kelompok eksperimen lebih tinggi dibandingkan kelompok kontrol.

Secara umum, hasil penelitian yang dilakukan sudah berjalan sesuai dengan tujuan pelaksanaan yang disusun dengan optimal. Hasil penelitian menunjukan bahwa terdapat pengaruh yang signifikan model pembelajaran VCT berbasis tri kaya parisudha terhadap sikap sosial siswa pada mata pelajaran PKn kelas V SD Gugus VI Kecamatan Tegalalang Tahun Pelajaran 2018/2019. Ada beberapa faktor yang menyebabkan keberhasilan model pembelajaran $V C T$ berbasis tri kaya parisudha sebagai berikut.

Tahap pertama model pembelajaran VCT adalah kebebasan memilih. Siswa diberikan secara bebas memilih nilai atau keputusan yang dianggap benar. Sari \& suwandi (2018) menjelaskan bahwa student will be more independent in making decisions and directing their own lives, yang akan membuat siswa aktif dalam proses pembelajaran. Dalam ajaran tri kaya parisudha kebebasan memilih termasuk pada bagian berpikir (manacika) siswa dituntut untuk berpikir yang baik (Rosalina, 2017). dengan indikator sikap sosial yaitu jujur dan kreatif. Hal ini tampak dari kegiatan siswa ketika diberikan ulangan siswa sangat jujur mengerjakannya tanpa menyontek pekerjaan temannya, siswa jujur mengerjakan tugastugas yang diberikan oleh guru dan siswa lebih kreatif dalam berfikir sehingga mampu menciptakan hal-hal baru seperti membbuat yel-yel dalam proses pembelajaran berlangsung yang berdampak pada sikap sosial siswa yang meningkat. Suharyat (2009) menyatakan sikap pada dasarnya merupakan hasil dari proses dan interaksi seseorang dengan lingkungannya yang merupakan perwujudan dari pikiran, perasaan seseorang serta penilaian terhadap objek yang didasari pada pengetahuan, pemahaman, pendapat dan keyakinan yang menghasilkan suatu kecenderungan untuk bertindak pada suatu objek.

Tahap kedua model pembelajaran VCT adalah menghargai. Pada tahap menghargai, Nunuk (2012) menyatakan bahwa adanya perasaan senang dan bangga dengan nilai yang menjadi pilihannya sehingga nilai tersebut akan menjadi bagian integral dari dirinya, bila kita menganggap nilai itu sudah pilihan maka dengan penuh kesadaran akan berani untuk ditunjukan di depan orang lain. Hal ini tampak pada pembelajaran saat guru telah menyampaikan topik-topik yang akan dibahas pada siswa. Siswa menyampaikam pendapatnya sesuai dengan hasil diskusi dan keyakinannya atas pendapatnya dengan baik (dalam ajaran tri kaya parisudha termasuk pada bagian wacika). Ketika siswa menyampaikan pendapatnya, siswa yang lain selalu menghargai pendapat dari temannya. Sikap sosial yang muncul pada proses pembelajaran yaitu siswa lebih demokratis dan disiplin dalam mengikuti pembelajaran. Febrianti (2017) menyatakan bahwa disiplin akan 
membuat seseorang tahu dan dapat membedakan hal-hal apa yang seharusnya dilakukan, yang boleh dilakukan, yang sepatutnya dilakukan karena merupakan hal-hal yang dilarang. Temuan ini sejalan dengan hasil penelitian Krisna (2016) yang mengungkapkan bahwa dengan teknik klarifikasi nilai terbukti dapat meningkatkan karakter kewarganegaraan siswa dengan cara meningkatkan disiplinnya.

Tahap ketiga model pembelajaran VCT adalah berbuat. Nunuk (2012) menyatakan bahwa kemauan dan kemampuan untuk mencoba melaksanakan dan mengulangi perilaku sesuai dengan nilai pilihannya. Hal ini tampak dari kegiatan diskusi kelompok siswa secara aktif dan antusias untuk memecahkan pertanyaan yang ada di LKS yang diberikan oleh guru dalam proses pembelajaran dan siswa mempresentasikan hasil diskusinya dengan penuh percaya diri (dalam ajaran tri kaya parisudha termasuk dalam kayika) yaitu berbuat yang baik dalam melaksanakan diskusi kelompok. Hal tersebut membuktikan pernyataan Nurdyansyah (2016) menyatakan bahwa model pembelajaran VCT memiliki kelebihan yaitu , (1) pendidikan nilai membantu peserta didik untuk berproses menyadari dan mengidentifikasi nilai-nilai mereka sendiri serta nilai-nilai orang lain; (2) pendidikan niali membantu peserta didik untuk mampu berkomunikasi secara terbuka dan jujur dengan orang lain, berhubungan dengan nilai-nilainya sendiri; dan (3) pendidikan nilai membantu peserta didik supaya mereka mampu menggunakan secara bersama-sama kemampuan berpikir rasional dan kesadaran emosional, untuk memahami perasaan, nilai-nilai, sikap dan pola tingkah laku.

Berbeda dengan pembelajaran PKn yang menggunakan model pembelajaran konvensional, selama proses pembelajaran siswa terlibat kurang kreatif dan aktif. Hal ini terlihat dalam proses pembelajaran masih menggunakan pembelajaran yang sedang berlangsung di sekolah pada kelompok kontrol yaitu masih menggunakan metode seperti ceramah, tanya jawab dan diskusi dengan sintak yang dilakukan secara terus menerus dan berulang dengan kata lain sintak dalam proses pembelajaran yang menoton yang mengakibatkan siswa kurang antusias dalam mengikuti pembelajaran di kelas dan kurang memperhatikan penjelasan guru.

Kegiatan pembelajaran konvensional dalam proses pembelajaran yang berpusat pada guru kurang memberikan siswa kesempatan bertanya karena kegiatan pembelajaran masih didominasi oleh guru yang membuat siswa merasa bosan, mengantuk, dan tidak menarik perhatian dalam proses pembelajaran. Dalam proses pembelajaran siswa kurang disiplin mengikuti pembelajaran. Seperti saat proses pembelajaran berlangsung siswa bercanda pada saat kegiatan diskusi kelompok. Ada juga siswa yang keluar kelas tidak permisi kepada guru yang sedang mengajar. Dengan demikian siswa dalam mengikuti pembelajaran konvensional belum mencapai indikator sikap sosial siswa belum terlihat dalam proses pembelajaran.

Berdasarkan temuan-temuan pada kelompok siswa yang dibelajarkan dengan menggunakan model pembelajaran VCT maupun kelompok siswa yang menggunakan model pembelajaran konvensional. Sikap sosial siswa yang dibelajarkan dengan menggunakan model pembelajaran VCT lebih baik dibandingkan dengan siswa yang tidak dibelajarkan dengan menggunakan model pembelajaran konvensional. Hasil penelitian yang diperoleh pada penelitian ini juga sejalan dengan penelitian yang dilakukan oleh Penelitian yang dilakukan oleh Arta (2013) bahwa terdapat perbedaan hasil belajar PKn yang signifikan antara siswa yang mengikuti pembelajaran menggunakan model pembelajaran Value Clarification Teenique dengan siswa yang mengikuti pembelajaran konvensional pada siswa kelas V semester ganjil tahun pelajaran2013/2014 di SD Gugus XV Kecamatan Buleleng Kabupaten Buleleng.

Hasil penelitian ini juga diperkuat oleh Budisrtini (2013) menyimpulkan bahwa terdapat perbedaan yang signifikan antara hasil belajar PKn siswa yang dibelajarkan menggunakan model pembelajaran Value Clarification Technique (VCT) berbantuan Media Power Point dengan siswa yang dibelajarkan menggunakan pembelajaran konvensional, Author F, Author S. (2012). 
khususnya pada materi Keutuhan Negara Kesatuan Republik Indonesia (NKRI). Hasil penelitian serupa juga pernah dilakukan oleh Pratama (2013) menyimpulkan bahwa terdapat perbedaan hasil belajar yang signifikan antara kelompok siswa yang dibelajarkan menggunakan pembelajaran Value Clarification Technique (VCT) dan kelompok siswa yang dibelajarkan menggunakan pembelajaran konvensional.

Berdasarkan paparan di atas, maka dapat disimpulkan bahwa terdapat pengaruh yang signifikan model pembelajaran VCT berbasis tri kaya parisudha terhadap sikap sosial siswa pada mata pelajaran PKn kelas V SD Gugus VI Kecamatan Tegalalang Tahun Pelajaran 2018/2019.

\section{SIMPULAN}

Berdasarkan hasil analisis data dan pembahasan dapat ditarik simpulan bahwa terdapat pengaruh model pembelajaran Value Clarification Technique (VCT) berbasis tri kaya parisudha terhadap Sikap Sosial Siswa Pada Mata Pelajaran PKn Kelas V SD Gugus VI Kecamatan Tegalalang Tahun Pelajaran 2018/2019. Perbedaan perhitungan ini dapat dibuktikan dengan perhitungan uji-t yang dilakukan pada skor akhir pada kelompok eksperimen dan kelompok control. Hasil perhitungan uji-t menunjukan bahwa $t_{\text {hitung }}$

sebesar 13,376. $t_{\text {hitung }}$ tersebut selanjutnya dibandingkan dengan $t_{\text {tabel }}$ pada taraf signifikansi $5 \%$ dengan $\mathrm{db}=\mathrm{n} 1+\mathrm{n} 2-2=28+31-2=59-2=57$ adalah sebesar 2,002. Hasil tersebut menunjukan bahwa $t_{\text {hitung }}>t_{\text {tabel }}(13,376>2,002)$, sehingga $H_{0}$ ditolak dan $H_{1}$ diterima. Selain perhitungan analisis data yang dilakukan pada penelitian, peneliti juga melakukan pengamatan sikap sosial siswa pada proses pembelajaran maka dapat ditemukan bahwa skor pengamatan sikap sosial siswa pada kelompok eksperimen lebih tinggi dibandingkan dengan kelompok kontrol. Hal tersebut dapat dibuktikan dengan skor yang diperoleh pada pengamatan sikap sosial dan post test. Hal ini berarti terdapat pengaruh yang signifikan model pembelajaran VCT berbasis tri kaya parisudha terhadap sikap sosial ssiswa pada mata pelajaran PKn siswa kelas V SD Gugus VI Kecamatan Tegalalang Tahun Pelajaran 2018/2019.

\section{SARAN}

Berdasarkan simpulan penelitian di atas, ada beberapa saran yang dapat disampaikan yaitu sebagai berikut.

Bagi Siswa, dalam kegiatan pembelajaran agar selalu aktif dalam proses pembelajaran sehingga mendapatkan pengetahuan baru melalui pengalaman sendiri dan dalam proses pembelajaran selalu tertib mengikuti pembelajaran sehingga dapat mengembangkan sikap sosial yang baik. Bagi guru, hendaknya lebih menekankan model pembelajaran yang inovatif, salah satunya adalah dengan model pembelajaran VCT berbasis tri kaya parisudha yang mampu mengembangkan sikap sosial siswa dalam proses pembelajaran. Bagi Kepala Sekolah, hendaknya mampu mengambil tindakan dalam upaya meningkatkan sikap sosial siswa melalui pengarahan kepada guru-guru sebagai fasilitator agar dapat mengembangkan model pembelajaran yang inovatif, salah satunya adalah model pembelajaran VCT berbasis tri kaya parisudha.

\section{DAFTAR RUJUKAN}

Dianti, P. (2016). Integrasi Pendidikan Karakter Dalam Pembelajaran Pendidikan Kewarganegaraan Untuk Mengembangkan Karakter Siswa. Jurnal Pendidikan Ilmu Sosial, 23(1). 
Ismail, H. F. (2015). Pro Kontra Ujian Nasional. Al-Riwayah: Jurnal Kependidikan, $7(2), 301-324$.

Krisna. (2016) "Pengaruh Penggunaan Teknik Klarifikasi Nilai Terhadap Penbentukan Civic Disposition Pada Mata Pelajaran PKn Kelas X sma Negeri 1 Piyungan" Jurnal Pendidikan Kewarganegaraan dan Hukum

Nurdyansyah \& Fahyuni E. . 2016. Inovasi Model Pembelajaran. Surabaya: Nizamia Learning Center.

Rosalina, P.D. 2017. "The Implementation Of Hindu Philosophy Tri Kaya Parisudha For Sustainable Tourism In Munduk Village North Bali" : STPBI Volume 3 Nomor 2 (Hal 224)

Rustiana. 2018. "Philosophy Tri Kaya Parisudha as Moderators the Effect of Equity Sensitivity and Ethical Sensitivity on Auditor's Ethical Behavior in Financial Audit Board of Republic Indonesia (BPK RI) Representatives of Bali Province". International Journal of Sciences: Basic and Applied Research. Vol. 40, No. 2 (hlm. 194).

Sari, I.P, \& Suwandi, I. K (2018) Nationalism Character Building by Value Clarification Techque (VCT). In Proceeding of PGSD UST International Conference on Education (Vol, 1). Suharyat, Y. (2009). Hubungan antara sikap, minat dan perilaku. Jurnal Region, 1(3), 1-19.

Susanto, Ahmad. 2013. Teori Belajar dan Pembelajaran di Sekolah Dasar.Jakarta: Kencana Prenada Media Group 